\title{
Indigenous Traditional Tools and Implements Used in Agriculture and Allied Sector in Tripura
}

\author{
Utpal Giri $^{1 *}$, Niladri Paul ${ }^{2}$, Dipankar De ${ }^{3,5}$, Soma Giri ${ }^{4}$ and M. C. Kundu ${ }^{5}$
}

${ }^{1}$ Department of Agronomy, College of Agriculture Tripura, Lembuchara, West Tripura799210, India

${ }^{2}$ Department of Soil Science and Agril. Chemicals, College of Agriculture Tripura, Lembuchara, West Tripura - 799210, India

${ }^{3}$ KVK, Khowai, Chebri, Khowai, Tripura, India

${ }^{4}$ KVK, North 24 Parganas Krishi Vigyan Kendra, Haripur, Ashokenagar, 743223, India

${ }^{5}$ Department of Soil Science and Agricultural Chemistry, PalliSiksha Bhavana (Institute of Agriculture), Visva-Bharati, Sriniketan 731236, Birbhum, West Bengal, India

*Corresponding author

\begin{tabular}{l} 
K e y w o r d s \\
Indigenous \\
technology \\
knowledge, Tools, \\
implements, \\
Tripura, Agriculture \\
Article Info \\
$\begin{array}{l}\text { Accepted: } \\
15 \text { April } 2020 \\
\text { Available Online: } \\
10 \text { May } 2020\end{array}$ \\
\hline
\end{tabular}

\section{A B S T R A C T}

Indigenous technology knowledge (ITK) refers to the exclusive, old-style, local thinking present and developed in and around the explicit situations of men and/or women native to a specific terrestrial area. Lots of indigenous agricultural know-how is available with the farming communities especially in tribal people of Tripura. Surveys were conducted in different districts of Tripura mainly in South Tripura, Gomati, Khowai, and West Tripura during November 2018 to June, 2019 for identifying and documenting the different Indigenous Traditional Knowledge used in Agriculture and allied agricultural activities. Survey was done through the method of using local resource persons and In-depth interview of farmers and notes, photos, audio and video recording were used for documentation. Some Indigenous Traditional implements which are still used by the people of Tripura for agriculture as well as allied sectors like in fisheries, animal husbandry etc. are documented. ITK is still an unprecedented resource in the development activities. It needs to be intensively and extensively studied and incorporated into formal research and extension practices in order to make rural development strategies more viable and sustainable. Special efforts are needed to understand, document and disseminate ITK for preservation, transfer or adoption elsewhere. 


\section{Introduction}

The attention on indigenous technical knowledge (ITK) involving the use of natural elements for solving the constraints or difficulties related to agricultural and other activities has induced in India in late eighties. Indian farmers acquired knowledge to produce food and live in constraint situation where they usually used various ITK for producing crops as their age-old tradition.

The enhancement of the quality of life of the Indians who in great majority live in and depend on agricultural production systems would be impossible by keeping this rich tradition of ITK aside (Prakash et al., 2019).Indigenous technology knowledge (ITK) can be defined as any information originated out of farmers experience which has practical utility in solving farmers problems which is feasible, profitable and socially acceptable and adopted farmers own conditions which moves from one generation to another by word of mouth (Sabarathnam, 1990). Indigenous technology knowledge (ITK) refers to the exclusive, old-style, local thinking present and developed in and around the explicit situations of men and/or women native to a specific terrestrial area (Prakash et al., 2019). Indigenous Technology Knowledge (ITK) is based on the experiences that gathered momentum through generation and are being developed and standardized through innumerable experimentation and practices to enhance the life of the people who greatly depend on agriculture production system.

\section{Characteristics of ITK}

Prakash et al., (2019) described the characteristics of ITK as - "ITK is not static but dynamic; Exogenous knowledge and endogenous creativity bring change to ITK; ITK is intuitive in its mode of thinking; ITK is mainly qualitative in nature; ITK study needs a holistic approach; ITK, if properly tapped, can provide valuable insights into resources, processes, possibilities and problems in particular area; ITK is recorded and transferred through oral tradition; ITK is learned through observation and hands-on experience; ITK forms an information base for variety; ITK reflects local tradition".

\section{Roles of ITK}

According to Prakash et al., (2019) the roles of ITK are - "ITK can aid development efforts; ITK can facilitate local people's participation; ITK is a valuable source of developing appropriate technologies".

\section{Scope of ITK analysis}

According to Prakash et al., (2019) the scope of ITK analysis are - "New biological and ecological insight; Resource management; Protected areas and conservation education; Development planning; and Environment assessment".

\section{Advantages of ITK}

Prakash et al., (2019) described the advantage of ITK as - "It has low cost and is readily available; ITK is found to be socially desirable, economically affordable, sustainable, environmentally safe and minimum risk to research users and widely believed to conserve resources; ITK provides basis for problem solving strategies for local communities; Use of ITK assures that the end user of specific development projects are involved in developing technologies appropriate to their needs".

Tripura being one of the eight sister state of the North Eastern India, is a land of beauty with a unique feature of land topography and cultural heritage. The state is covered by picturesque hills and dales, deep and green 
valley's which add beauty to its landscape. The State has rich natural resources; including gas and forests. Tripura $\left(22^{\circ} 56^{\prime}-24^{\circ} 32^{\prime}\right.$ North latitude and $91^{\circ} 10^{\prime}-92^{\circ} 21^{\prime}$ East longitude) is situated in one of the farthest corners of the country and three fourth of its boarder being shared with the Bangladesh on its North, South and West. Only communicable main land connection of the state is with Assam and Mizoram. Tripura having a population density of about 350 persons per sq.km., comprising a multitude of ethnic groups, tribes, religions, languages and dialects, yet a very much peaceful and sober state to live. The main livelihood of the people of the state depends mainly on Agriculture.

Tripura is one of the hotspots of bio-diversity. Tripura peoples are still using the traditional knowledge in agriculture particularly Tribal people. The survey work is carried out from November, 2018 to June, 2019. The results of research and survey for the year 2018-19 has been presented in this document, along with the methods and scope for ITK in the state of Tripura.

\section{Materials and Methods}

Process and methods used for ITK documentation (Pandey et al., 2017)

\section{Identification and collection of ITK}

Methods and techniques used during survey works are -

Use of local resource persons

Hear-say method

Survey method

Detailed talking with cultivators.

\section{Documentation}

Methods and Techniques for documentation used in survey are -
Notes

Photos

Audio-recordings

Video-recordings

\section{Area of survey work}

Extensive survey works were done in purposively selected regions Belonia and Rajnagar block in South Tripura district, Bamutia block in West Tripura district, Killablock in Gomati district and Khowaisubdivision in Khowai district for study and documentation of ITKs used by the local people of Tripura.

\section{Results and Discussion}

Lots of indigenous agricultural know-how is available with the farming communities especially in the tribal people. These traditional farming systems are products of centuries of accumulated experiences. Farmers all over the world have developed their own indigenous systems of farming with local inputs. Some of the ITKs are herewith documented with photographs and description in Table 1.

In conclusion, indigenous technology knowledge (ITK) is still an unprecedented resource in agricultural and rural development activities. The ITK requires to be studied intensively and exhaustively and should be included into the research as well as extension activities for sustainable rural development. Special efforts are to be needed for understanding, documenting and disseminating ITK for preservation, transfer or adoption elsewhere. Since, the ITK's seems to be cheaper, locally and easily available in rural areas and have lesser side effects, the use of these ITK's may be encouraged by formulating proper strategy mainly through training and demonstration. 
Table.1 Different indigenous traditional tools and implements observed during survey work in Tripura

\begin{tabular}{|c|c|c|c|c|c|c|}
\hline $\begin{array}{l}\text { Sl. } \\
\text { No }\end{array}$ & $\begin{array}{l}\text { Name of the } \\
\text { ITK }\end{array}$ & Function & $\begin{array}{l}\text { Photo of the } \\
\text { tools/implements }\end{array}$ & $\begin{array}{l}\text { Description of tools/ } \\
\text { implements }\end{array}$ & $\begin{array}{c}\text { Name of the } \\
\text { farmers from } \\
\text { whom } \\
\text { collected } \\
\end{array}$ & $\begin{array}{l}\text { Place of } \\
\text { collection }\end{array}$ \\
\hline 1 & $\begin{array}{l}\text { Sudam } \\
\text { (Kokborok } \\
\text { language) or } \\
\text { Fishing Trap }\end{array}$ & $\begin{array}{l}\text { It is mainly used by } \\
\text { Traditional or Indigenous } \\
\text { people. It is used as a } \\
\text { fishing trap to catch the } \\
\text { fishes in pond, lake, river } \\
\text { or in any water bodies. }\end{array}$ & & $\begin{array}{l}\text { It is made up of bamboo by } \\
\text { the local people. }\end{array}$ & $\begin{array}{l}\text { Mandira } \\
\text { Debbarma }\end{array}$ & $\begin{array}{l}\text { Hari kanto } \\
\text { para, Gabordi }\end{array}$ \\
\hline 2 & $\begin{array}{l}\text { Twi hook } \\
\text { (Kokborok } \\
\text { Language) }\end{array}$ & $\begin{array}{l}\text { It is mainly used by } \\
\text { Traditional or Indigenous } \\
\text { people. It is used for } \\
\text { carrying water bucket or } \\
\text { any hard items in more } \\
\text { number. }\end{array}$ & & $\begin{array}{l}\text { It is made up of bamboo by } \\
\text { the local people. It is round } \\
\text { shaped at the top and } \\
\text { becoming narrow towards } \\
\text { bottom. }\end{array}$ & $\begin{array}{l}\text { Meselha } \\
\text { Molsom }\end{array}$ & $\begin{array}{l}\text { Darjeeling, } \\
\text { Killa }\end{array}$ \\
\hline 3 & $\begin{array}{l}\text { Rusham\& } \\
\text { Romo } \\
\text { (Kokborok } \\
\text { language) or } \\
\text { Denki or Man } \\
\text { operated Rice } \\
\text { miller }\end{array}$ & $\begin{array}{l}\text { It is mainly used for } \\
\text { making flour specially } \\
\text { from paddy grain and } \\
\text { sometime other grains are } \\
\text { also placed for making } \\
\text { flour. }\end{array}$ & & $\begin{array}{l}\text { It is made up of wood by the } \\
\text { local people. Instead of } \\
\text { mechanical grinder in market, } \\
\text { the local people use it for } \\
\text { making ground of paddy/ rice } \\
\text { or other materials. It consists } \\
\text { of one rod shaped woody hard } \\
\text { structured and one round } \\
\text { shaped which is concaved in } \\
\text { the middle. }\end{array}$ & $\begin{array}{l}\text { Tiyari } \\
\text { Debbarma }\end{array}$ & $\begin{array}{l}\text { Hari kanto } \\
\text { para, Gabordi }\end{array}$ \\
\hline
\end{tabular}




\begin{tabular}{|c|c|c|c|c|c|c|}
\hline 4 & $\begin{array}{l}\text { Janta (in } \\
\text { Bengali/ local } \\
\text { language) or } \\
\text { pulse breaker }\end{array}$ & $\begin{array}{l}\text { It is mainly used to break } \\
\text { whole pulse grain by } \\
\text { crushing them into it to } \\
\text { make edible pulse. }\end{array}$ & 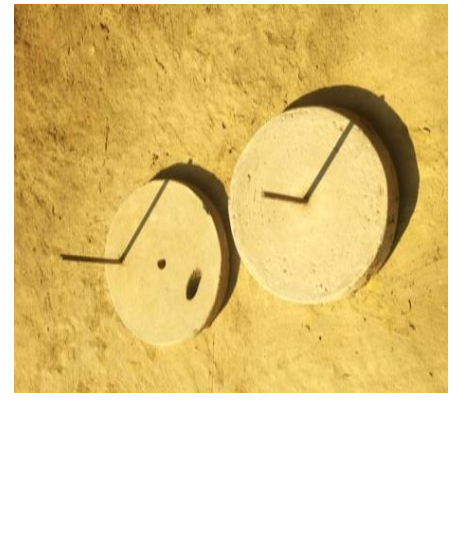 & $\begin{array}{l}\text { It is made up of stone or } \\
\text { cement. It consists of two } \\
\text { round shaped cemented } \\
\text { structure of equal sizes. These } \\
\text { two parts are connected with } \\
\text { iron rod which is fixed with } \\
\text { one cemented part. The non- } \\
\text { fixed part has an hole where } \\
\text { through pulses or any other } \\
\text { material which need to be } \\
\text { grinded are placed. }\end{array}$ & Sripati Datta & $\begin{array}{l}\text { Chittamara, } \\
\text { Belonia }\end{array}$ \\
\hline 5 & $\begin{array}{l}\text { Sishing } \\
\text { (Kokborok } \\
\text { language) or } \\
\text { fishing trap }\end{array}$ & $\begin{array}{l}\text { It is mainly used for Fish } \\
\text { trapping }\end{array}$ & & $\begin{array}{l}\text { It is made up of bamboo by } \\
\text { the local people with a trap to } \\
\text { captured the fishes. }\end{array}$ & $\begin{array}{l}\text { TiyariDebbar } \\
\text { ma }\end{array}$ & Gabordi \\
\hline 6 & $\begin{array}{l}\text { Dengki or } \\
\text { man operated } \\
\text { rice miller }\end{array}$ & $\begin{array}{l}\text { It is mainly used for } \\
\text { milling of rice. Earlier } \\
\text { days when milling } \\
\text { machine was not } \\
\text { available, it was being } \\
\text { used by the people for } \\
\text { preparing rice from } \\
\text { paddy. }\end{array}$ & 20 & $\begin{array}{l}\text { It is made up of wood. It } \\
\text { consists of long woody } \\
\text { structured which is fixed at } \\
\text { one end with two stalks fixed } \\
\text { with earth where pressure is } \\
\text { given by the legs to pull the } \\
\text { other end like a liver and one } \\
\text { relatively narrow peg is fixed } \\
\text { at right angle at the other end } \\
\text { which strikes the paddy grains } \\
\text { kept in the container. The }\end{array}$ & $\begin{array}{l}\text { Nakul } \\
\text { Debnath }\end{array}$ & Salema \\
\hline
\end{tabular}




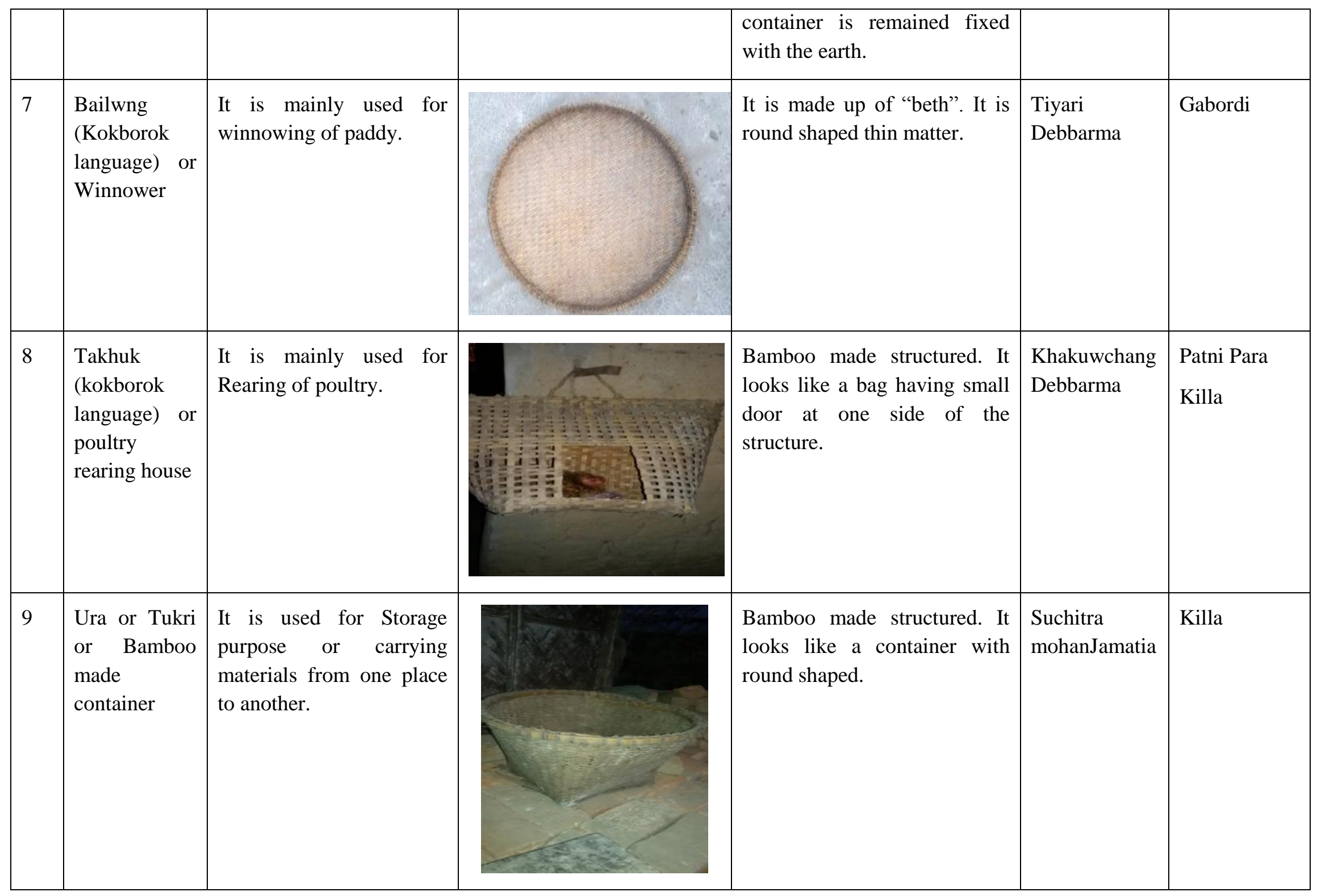




\begin{tabular}{|c|c|c|c|c|c|c|}
\hline 10 & $\begin{array}{l}\text { Dol( } \\
\text { kokborok } \\
\text { language) or } \\
\text { granary }\end{array}$ & $\begin{array}{l}\text { It is used for store the } \\
\text { paddy grain for long } \\
\text { purpose. }\end{array}$ & & $\begin{array}{l}\text { Bamboo made plastered with } \\
\text { mud. }\end{array}$ & $\begin{array}{l}\text { Suchitra } \\
\text { mohanJamatia }\end{array}$ & Killa \\
\hline 11 & $\begin{array}{l}\text { Jangini } \\
\text { (kokborok } \\
\text { language) or } \\
\text { drying tool }\end{array}$ & $\begin{array}{l}\text { It is used as a object in } \\
\text { which other material are } \\
\text { kept and let them for } \\
\text { drying in sun. }\end{array}$ & & $\begin{array}{l}\text { It is made off of bamboo and } \\
\text { looks like sieve. }\end{array}$ & $\begin{array}{l}\text { Suchitra } \\
\text { mohanJamatia }\end{array}$ & Killa \\
\hline 12 & $\begin{array}{l}\text { Indigenous } \\
\text { plough }\end{array}$ & $\begin{array}{l}\text { It is used for ploughing } \\
\text { the soil. }\end{array}$ & 1 & It is a wood structured. & $\begin{array}{l}\text { Durga Manik } \\
\text { Jamatia }\end{array}$ & $\begin{array}{l}\text { Noabari, } \\
\text { Killa }\end{array}$ \\
\hline 13 & $\begin{array}{l}\text { Jowal } \\
\text { (kokborok / } \\
\text { Bengali } \\
\text { language) } \\
\text { or Yoke }\end{array}$ & $\begin{array}{l}\text { It is used for attaching } \\
\text { two bullocks during } \\
\text { ploughing by indigenous } \\
\text { plough. }\end{array}$ & is. & $\begin{array}{l}\text { Wood or bamboo made } \\
\text { material. }\end{array}$ & $\begin{array}{l}\text { Durga Manik } \\
\text { Jamatia }\end{array}$ & $\begin{array}{l}\text { Noabari, } \\
\text { Killa }\end{array}$ \\
\hline
\end{tabular}




\begin{tabular}{|c|c|c|c|c|c|c|}
\hline 14 & $\begin{array}{l}\text { Khupa } \\
\text { (kokborok } \\
\text { language) }\end{array}$ & $\begin{array}{l}\text { It is used for closing of } \\
\text { cattle mouth during } \\
\text { ploughing. }\end{array}$ & 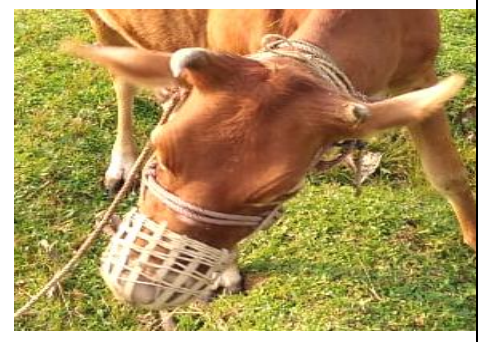 & $\begin{array}{l}\text { It is prepared by bamboo or } \\
\text { nylon net with rope which is } \\
\text { used to close the mouth of } \\
\text { cattle during ploughing so that } \\
\text { they will not eat any grasses } \\
\text { and do not waste any time. }\end{array}$ & $\begin{array}{l}\text { Durga Manik } \\
\text { Jamatia }\end{array}$ & $\begin{array}{l}\text { Noabari, } \\
\text { Killa }\end{array}$ \\
\hline 15 & $\begin{array}{l}\text { Dapa } \\
\text { (kokborok } \\
\text { language) or } \\
\text { smoking tool }\end{array}$ & $\begin{array}{l}\text { It is used for smoking } \\
\text { purpose. }\end{array}$ & & $\begin{array}{l}\text { It is normally made of } \\
\text { bamboo used for smoking of } \\
\text { hookah, cheroot etc. }\end{array}$ & $\begin{array}{l}\text { Durga Manik } \\
\text { Jamatia }\end{array}$ & $\begin{array}{l}\text { Noabari, } \\
\text { Killa }\end{array}$ \\
\hline 16 & $\begin{array}{l}\text { Washung } \\
\text { Gudak } \\
\text { (Kokborok } \\
\text { language) or } \\
\text { dry fish } \\
\text { making tool }\end{array}$ & $\begin{array}{l}\text { It is used for making } \\
\text { gudak or dry fish. }\end{array}$ & & It is made by bamboo. & $\begin{array}{l}\text { Subhash } \\
\text { DayalJamatia }\end{array}$ & $\begin{array}{l}\text { Twirupa } \\
\text { Bari, Killa }\end{array}$ \\
\hline
\end{tabular}




\begin{tabular}{|c|c|c|c|c|c|}
\hline 17 & $\begin{array}{l}\text { Natai } \\
\text { Or charki }\end{array}$ & $\begin{array}{l}\text { Thread is prepared from } \\
\text { cotton by Spinning the } \\
\text { thread with this. }\end{array}$ & It is made by wood. & KVK, Khowai & Khowai \\
\hline 18 & $\begin{array}{l}\text { Baatibokhrok } \\
\text { and patina }\end{array}$ & $\begin{array}{l}\text { It is used for preparation } \\
\text { of local alcoholic } \\
\text { beverages or wine by the } \\
\text { tribal people by boiling } \\
\text { the rice which is kept for } \\
\text { soaking for 2-3 days. }\end{array}$ & $\begin{array}{l}\text { It consists of one aluminum } \\
\text { container, three earthen pots } \\
\text { and two long channels made } \\
\text { off of bamboo or wood. Ricce } \\
\text { is boiled in earthen pot with } \\
\text { the help of hot steam which is } \\
\text { evaporated from the } \\
\text { aluminum container by } \\
\text { applying stem at the bottom of } \\
\text { the container. The steam } \\
\text { evaporated from the boiled } \\
\text { riec is collected in other two } \\
\text { earthen pots through the } \\
\text { bamboo made channels and } \\
\text { the earthen pots are cooled } \\
\text { with cold water so that it } \\
\text { becomes liquid which is the } \\
\text { ultimat product. }\end{array}$ & Hiran Tripura & $\begin{array}{l}\text { Chittamara, } \\
\text { Belonia }\end{array}$ \\
\hline
\end{tabular}




\begin{tabular}{|c|c|c|c|c|c|c|}
\hline 19 & $\begin{array}{l}\text { Bol or } \\
\text { Bamboo stalk }\end{array}$ & $\begin{array}{l}\text { It is use for carrying } \\
\text { harvested paddy from the } \\
\text { field to the threshing } \\
\text { floor. }\end{array}$ & $\sum_{--1}^{2}$ & It's a bamboo made stick. & $\begin{array}{l}\text { Narendra } \\
\text { Tripura }\end{array}$ & $\begin{array}{l}\text { Chittamara, } \\
\text { Belonia }\end{array}$ \\
\hline 20 & $\begin{array}{l}\text { Bamboo } \\
\text { made sprayer }\end{array}$ & $\begin{array}{l}\text { Spraying of pesticides is } \\
\text { done in absence of } \\
\text { sprayer }\end{array}$ & & $\begin{array}{l}\text { It is bamboo made having two } \\
\text { nodes. One side has small hole } \\
\text { and other side of the bamboo } \\
\text { has bigger hole where through } \\
\text { valve will be inserted. Small } \\
\text { hole is made where through } \\
\text { water or spray material will be } \\
\text { emerged when pressure will } \\
\text { be given at the other side } \\
\text { through a valve type bamboo } \\
\text { made parts by the hand. }\end{array}$ & $\begin{array}{l}\text { Raghuram } \\
\text { Tripura }\end{array}$ & $\begin{array}{l}\text { Chittamara, } \\
\text { Belonia }\end{array}$ \\
\hline 21 & $\begin{array}{l}\text { Tanth (Man } \\
\text { weaving } \\
\text { machine) }\end{array}$ & $\begin{array}{l}\text { it is used for making } \\
\text { cloth. Handmade cotton } \\
\text { "saree", locally called } \\
\text { "tanthersharee" } \\
\text { prepared by using this } \\
\text { tools. }\end{array}$ & 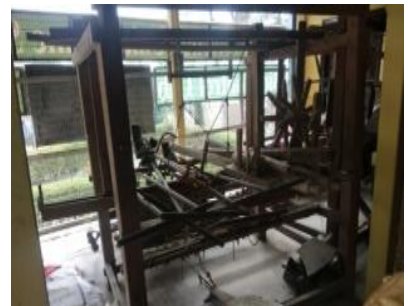 & $\begin{array}{l}\text { This is mainly wooden made } \\
\text { having various parts. Different } \\
\text { parts have different functions. } \\
\text { One man can produce 2-3 } \\
\text { "sharre"s per day. }\end{array}$ & KVK, Khowai & $\begin{array}{l}\text { Chebri, } \\
\text { Khowai }\end{array}$ \\
\hline
\end{tabular}




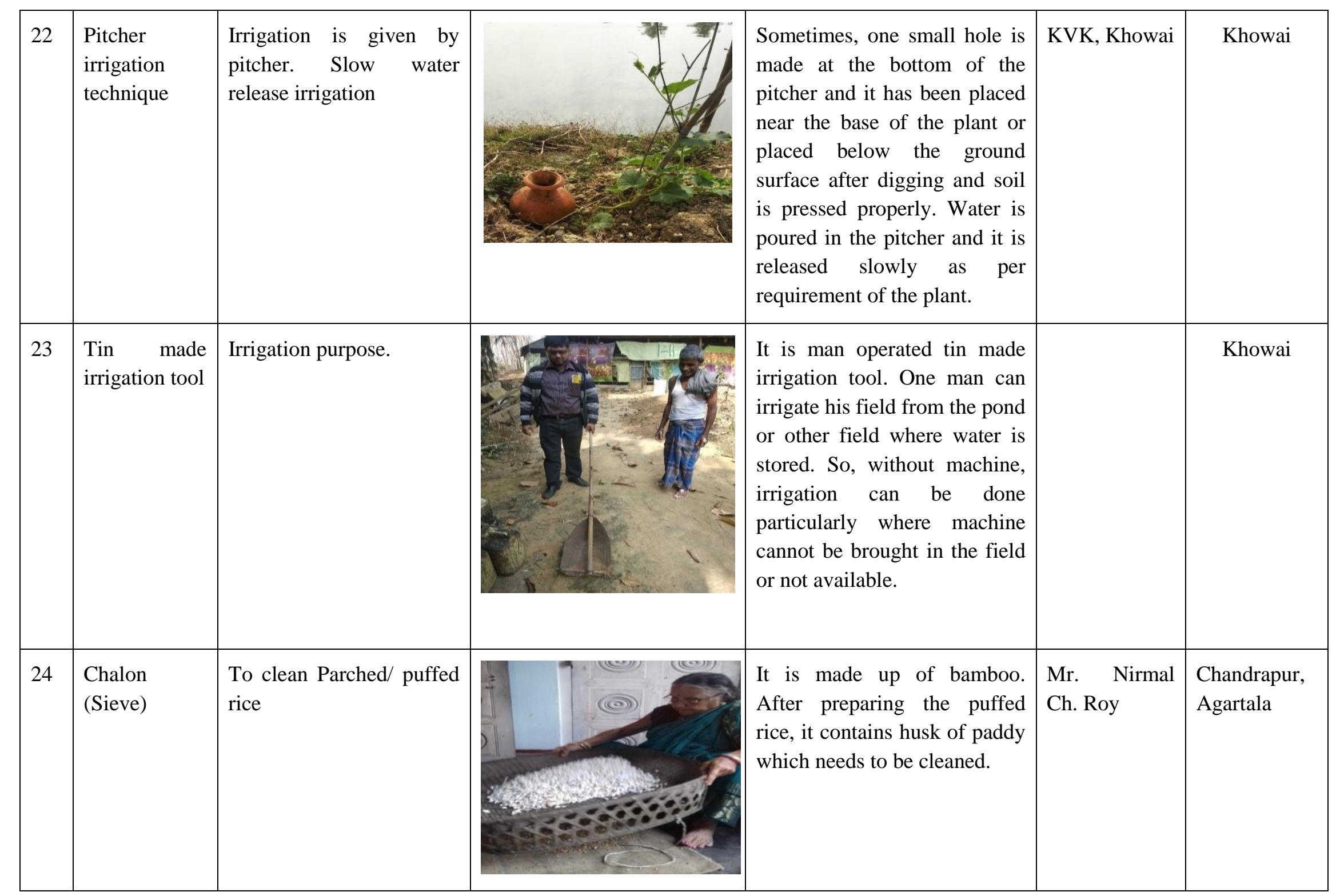




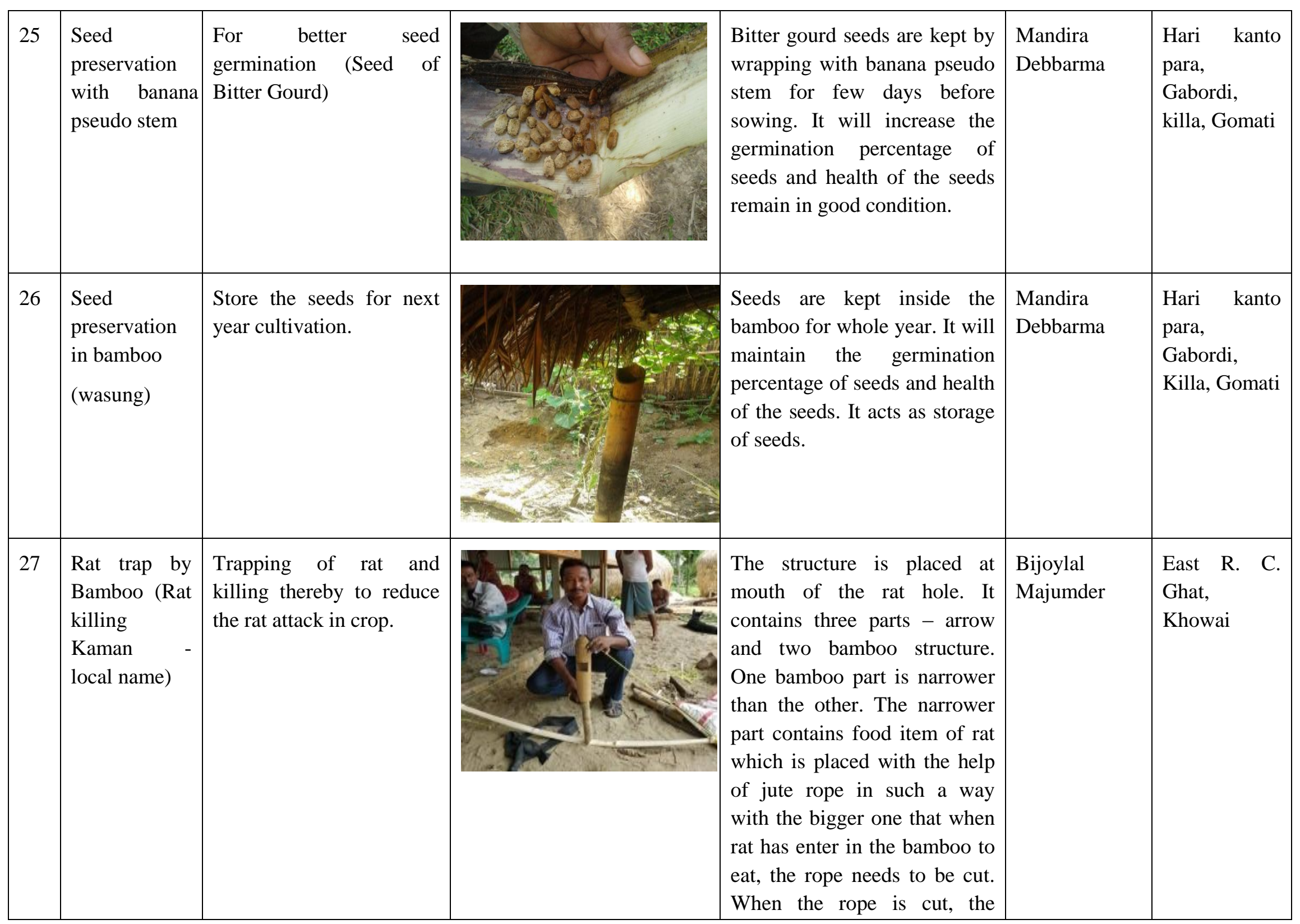




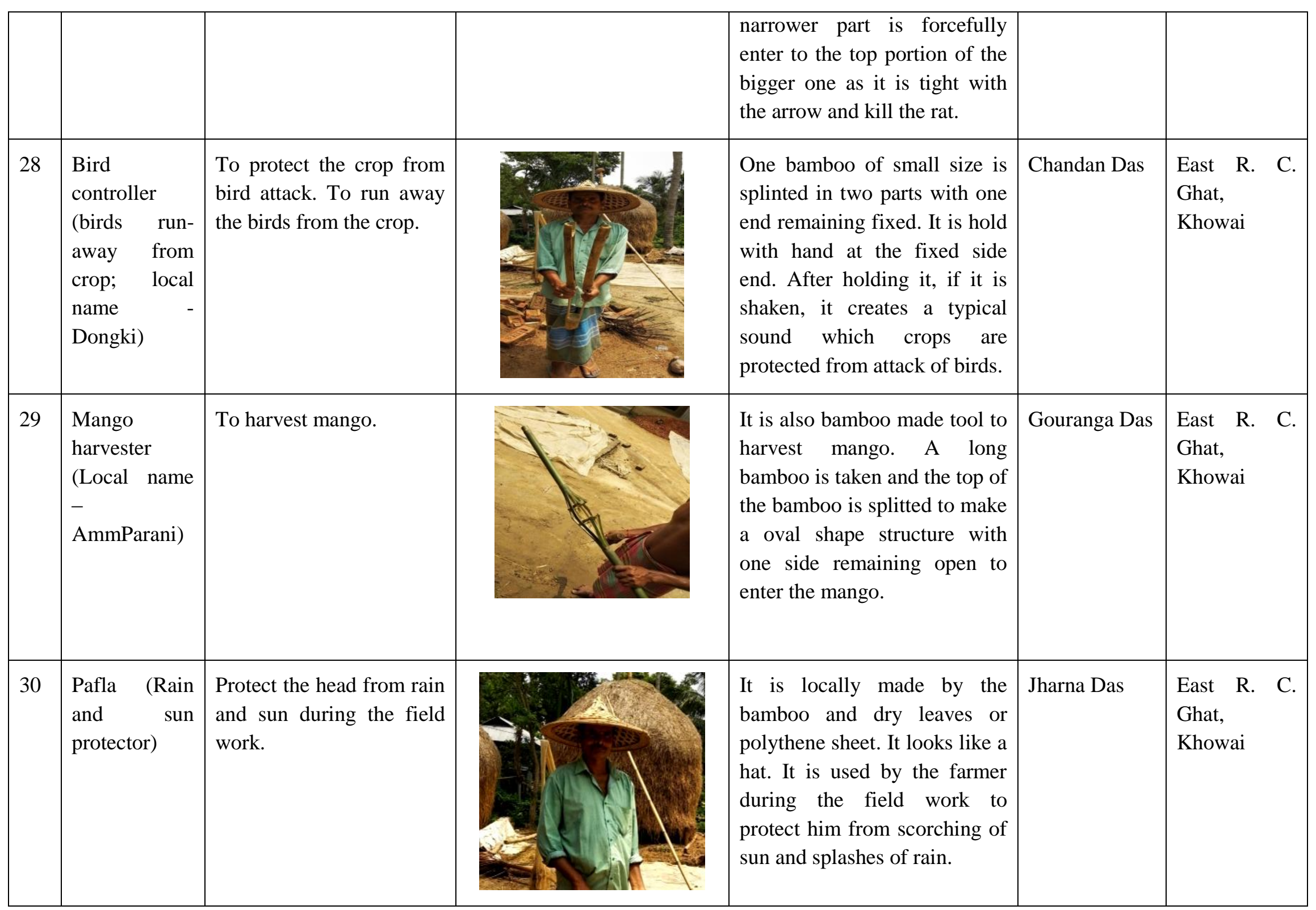




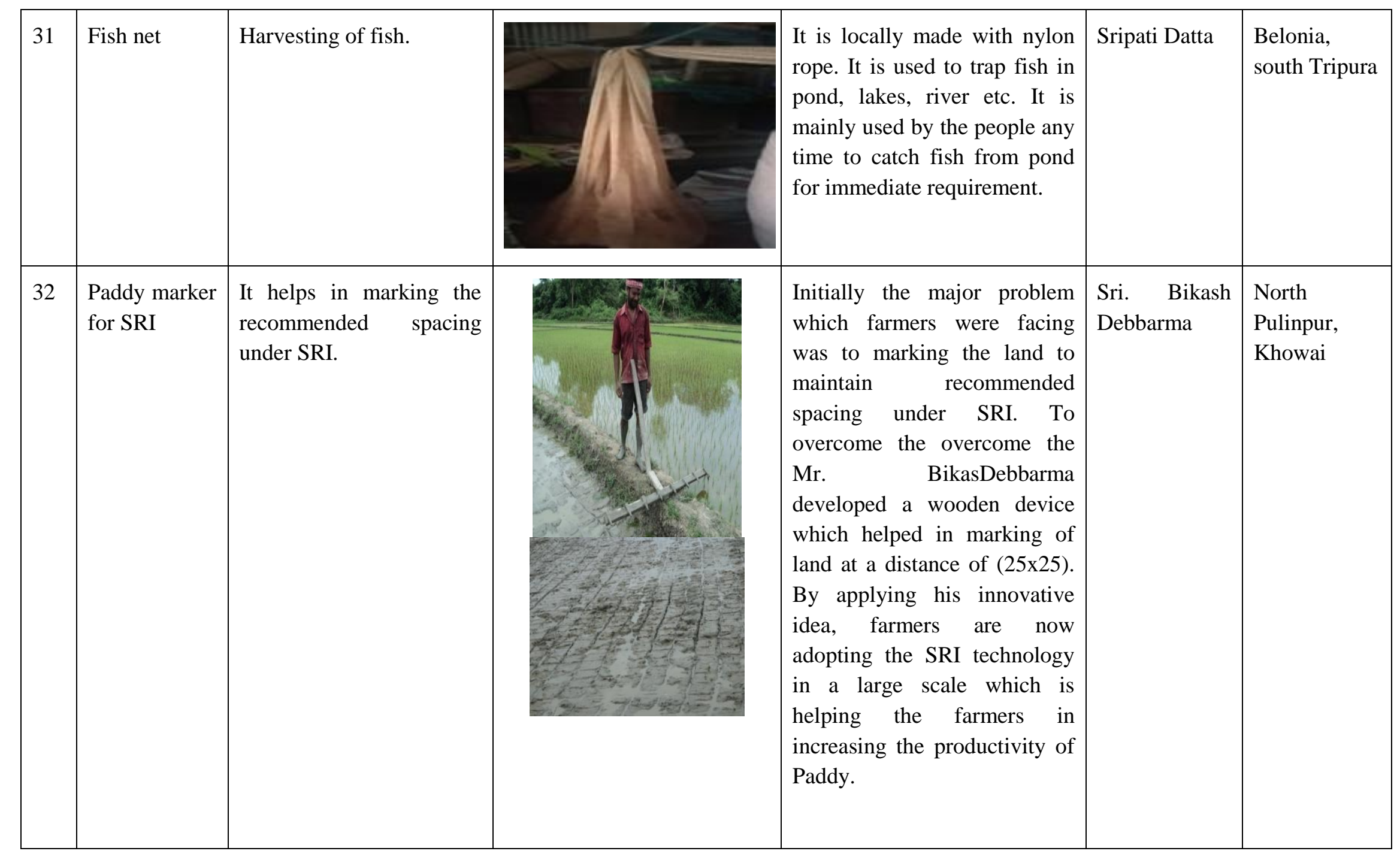




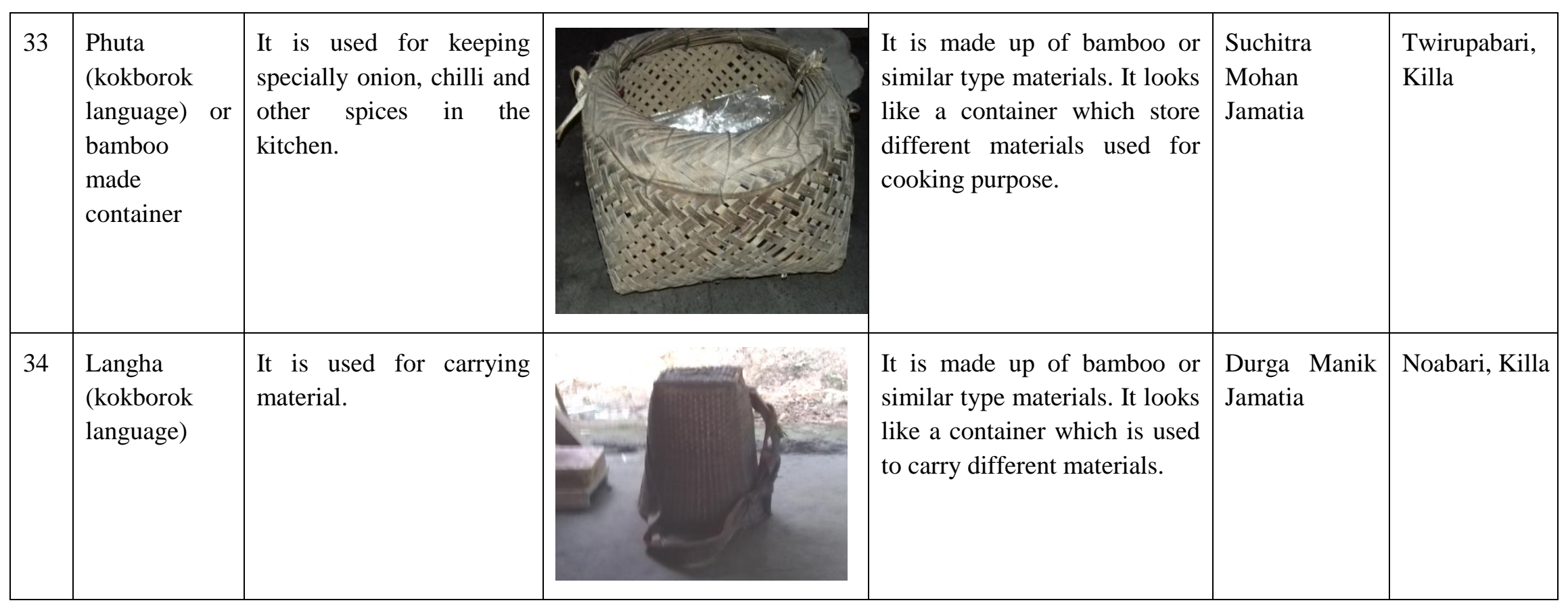




\section{Acknowledgement}

We acknowledge the Tripura Biodiversity Board, Gorkhabasti, Agartala for supporting and funding the survey work and the farmers who have helped in collection of information about the indigenous tools and implements used in agriculture and allied sector.

\section{References}

Grenier, L. 1998. Working with Indigenous Knowledge: A guide for Researchers, (International Development Research Centre, Ottawa, Canada).

Pandey, V., Mittal, R.and Sharma, P. 2017. Documentation and Application of Indigenous Traditional Knowledge (ITK) for Sustainable Agricultural
Development. Asian Journal of Agricultural Extension, Economics \& Sociology. 15(3): 1-9.

Prakash, N., Roy, S.S. and Ngachan, S.V. 2019. Role of ITK in Conservation Agriculture: Blending Indigenous and Scientific Knowledge, (ICAR Research Complex for NEH Region, Umiam 793103, Meghalaya), http://kiran.nic.in/pdf/publications/ITK. pdf downloaded on 18.06.2019.

Sabarathnam, V.E. 1990. Report of training on Agricultural Research Management with an emphasis on technology management in agriculture in UNDP, (FAO Project at Iowa, USA, NAARM, Rajendranagar, Hyderabad - 500030.

\section{How to cite this article:}

Utpal Giri, Niladri Paul, Dipankar De, Soma Giri and Kundu, M. C. 2020. Indigenous Traditional Tools and Implements Used in Agriculture and Allied Sector in Tripura. Int.J.Curr.Microbiol.App.Sci. 9(05): 2102-2117. doi: https://doi.org/10.20546/ijcmas.2020.905.241 